\title{
EDUCATION AS A TOOL OF THE CONSTITUTIONAL DUTY TO TACKLE HOMOPHOBIA: POTENTIALI- TIES AND STRUGGLES ${ }^{1}$
}

Daniel Carvalho Cardinali

Master in Law at Universidade do Estado do Rio de Janeiro. Lawyer.

E-mail: danielcardinali@hotmail.com

Received: 2017-10-21. Accepted:2017-12-05

\begin{abstract}
This article aims to analyze the role the school can play in the struggle against homophobia. The first part will examine homophobia, understood as an injustice in the cultural field that derives from a model of compulsory heterosexuality and male domination, which calls for politics of recognition. Then it will be analyzed in what fashion these politics of recognition are set on the Constitution of 1988, in order to conclude that it establishes an obligation of the State to adopt them. On the basis of this premise, the third part examines the privileged potential that school assumes in this scenario, addressing the central role it plays in the production of homophobia and the role it may play in its unmaking. Finally, the debates and tensions regarding the subject will be analyzed, especially those that arose of conservative and religious discourse and the formulation of the category of "gender ideology".
\end{abstract}

Keywords: Education - Homophobia - "Gender ideology" - Equality Recognition.

\section{INTRODUCTION}

The 1988 Federal Constitution is defined by the central role given to the dignity of the human person and the fundamental rights, symbolically posited in its beginning, and also the "profound and visceral commitment to equality" 2 in the quest for the construction of a more

1 Translated by Miguel Alencar Rosa Teixeira Mendes

2 SARMENTO, Daniel. "A Igualdade Étnico-Racial no Direito Constitucional Brasileiro: 
just and tolerant towards plurality Brazil. From this new axiological paradigm, the view of law as an instrument to social emancipation gains more relevance. Thus, the new constitutional order has served as the foundation to a series of new discourses and movements which aim to deconstruct atavistic cultural standards over which all sorts of prejudices and discriminations propagates. In this picture, the 1988 Charter is considered the "cornerstone from which sexuality and reproduction appear as legitimate fields in which to exercise rights in Brazil"', acting as normative basis for public policy developed in favor of sexual diversity and the combat against homophobia.

Despite this scenario, "sexual orientation" is not expressly posited in the prohibited modes of discrimination in art. $3^{\circ}$, IV of the Constitution. Its inclusion in this roster was the main request of the homosexual movement during the Constituent Assembly. However, the proposal fell short ${ }^{4}$ and the debates around the measure revealed an enormous resistance towards the theme from the parliament members who understood the inclusion of the term would stimulate libertine behavior, immorality, and debauchery, serving only to encourage "bad habits", ridicule the official institutions, and propagate the AIDS epidemic. 5

On the other hand, it seems indubious that discrimination by reason of sexual orientation is prohibited by the constitutional order of 1988, albeit implicitly. The opening of the cited art. $3^{\circ}$, IV, mentions "any other forms of discrimination", and the emancipatory spirit of the new Constitution allow this comprehension. ${ }^{6}$ In Roger Raupp Rios' opinion, sexual identity discrimination should be included in discrimination by reason of sex, which is explicitly prohibited by the constitutional text, as the homosexual subject is discriminated due to the sex of whom it

Discriminação 'De Facto', Teoria do Impacto Desproporcional e Ação Afirmativa”. In: SARMENTO, Daniel. Livres e Iguais: Estudos de Direito Constitucional. Rio de Janeiro: Lumen Juris, 2006, p. 141.

3 CARRARA, Sérgio. "Políticas e direitos sexuais no Brasil contemporâneo". In: Bagoas, no 05, 2010, p. 134.

4 Although it wasn't included in the Federal Constitution, the prohibition of discrimination by reason of sexual orientation was included in the State Constitution for Mato Grosso and Sergipe, and in the Organic Law of various municipalities.

5 The proposal received the unapologetic nickname of "sexual disorientation amendment" (TREVISAN, João Silvério. Devassos no Paraíso: a homossexualidade no Brasil, da colônia à atualidade. $8^{\mathrm{a}}$ Ed. Rio de Janeiro: Record, 2011, p. 158). About the propositions and debates of the constituent about the theme, see: MARMELSTEIN, George. "Jurisprudência arco-íris: comentários à decisão do Supremo Tribunal Federal acerca das uniões homoafetivas". In: Revista Brasileira de Direito Constitucional - RBDC, n. 17, 2011, pp. 233-235.

6 SARMENTO, Daniel. "Casamento e União Estável entre Pessoas do Mesmo Sexo: perspectivas constitucionais”. In: SARMENTO, Daniel; IKAWA, Daniela; PIOVESAN, Flávia (coords.). Igualdade, Diferença e Direitos Humanos. Rio de Janeito: Lumen Juris, 2010, p. 636. 
guides its affective-sexual involvement. ${ }^{7}$

Thus, from this premise, one can question which measures the constitutional order of 1988 demands from the State in face of that which is commonly called homophobia. Confronting this reality can be materialized in a complex array of actions of distinct orders, which range from repression and punishment of discriminatory behavior, to positive measures of intervention on reality in favor of sexual diversity. This article's focus is the second type of measure, analyzing how the adoption of public policy against homophobia in the field of education and schools have a privileged potential of social transformation, basing itself on Nancy Fraser's recognition theory.

The first part of the article will examine the problem to be faced, trying to comprehend homophobia as an injustice in the field of recognition due to asymmetrical and stigmatizing cultural standards, and which requires recognition policies for its confrontation, based on the theoretical keys developed by Nancy Fraser. Thus, its cultural basis, like the choosing of heterosexuality as the only legitimate/ possible sexual orientation and the male domination characterized by the stratification of gender roles and superiority of the masculine over the feminine will be summarized.

The second part will approach the constitutional duty of adoption of recognition policies for the facing of homophobia, analyzing its normative frameworks in the Brazilian constitutional order and, mainly, the necessity of adoption of positive measures of intervention in the reality which consubstantiates as public policies of valuing difference and pluralism.

Among those various measures, the intervention in the field of education has a privileged potential. Thus, the third section will first analyze in which way school acts as a normalizing and disciplining instance for the production and reproduction of a homophobic culture, and then explore the possibilities of school taking the role of deconstructing a culture of intolerance and prejudices.

Finally, the fourth and final part will approach the disputes and tensions that such policies face, due to the actions of religious and conservative groups which aim that schools act in reinforcing the notion of a monolithic model of family and sexual experience and oppose that which they call "gender ideology".

\section{HOMOPHOBIA AS A MATTER OF RECOGNITION}

Discrimination and prejudice suffered by people who have a

7 RIOS, Roger Raupp. "Direito da antidiscriminação, sexo, sexualidade e gênero: a compreensão da proibição constitucional de discriminação por motivo de sexo". In: SARMENTO, Daniel; IKAWA, Daniela; PIOVESAN, Flávia (coords.). Igualdade, Diferença e Direitos Humanos. Rio de Janeiro: Lumen Juris, 2010, pp. 714-717. 
non-heterosexual sexual orientation or affective-sexual practice, be it real or presumed/supposed ${ }^{8}$, are traditionally denominated homophobia. Although widely adopted in the academic and militant discourse, having popularized later, the term is criticized and alternatives are proposed. Some authors believe the use of the suffix -phobia could send the idea that it is a psychopathology of the individual order, erasing the social, cultural, legal, and institutional components of the discrimination. Other suggested terms put more focus in these aspects, e.g., heterosexism and heteronormativity. ${ }^{9}$

Due to its wide dissemination, the expression will be adopted in this article, making clear that the author adheres to the critic of the term, as the discrimination that non-heterosexual people suffer is not only due individual actions, but mainly due to the social, institutional, and cultural standards that produce them. ${ }^{10}$ Borrillo defines homophobia as:

The general, psychological, and social hostility
towards those who, supposedly, feel desire or
have sexual practices with individuals of their
own sex. A specific form of sexism, homophobia
rejects, equally, all of those who do not conform
with the predetermined role by their biological
sex. Ideological construct that consists in the
constant promotion of a form of sexuality (hetero)
in detriment of another (homo), homophobia
organizes an hierarchy of sexualities and, in this
way, extract political consequences.

It is noticeable that homophobia stems from a hierarchical system that values subjects in an asymmetrical way due to their sexual

\footnotetext{
8 An important case about this situation involved a father and son that, while embracing, were mistaken for a gay couple and assaulted in São João da Boa Vista, São Paulo, in 2011.

9 RIOS, Roger Raupp. "O conceito de homofobia na perspectiva dos direitos humanos e no contexto dos estudos sobre preconceito e discriminação". In: RIOS, Roger Raupp. (org.). Em Defesa dos Direitos Sexuais. Porto Alegre: Livraria do Advogado Ed., 2007, p. 120; JUNQUEIRA, Rogério Diniz. "Homofobia: limites e possibilidades de um conceito em meio a disputas". Revista Bagoas, V.1, n.1, jul./dez. 2007, p. 10.

10 On the other hand, even the individual reaction of visceral disgust, usually related to the notion of "phobia", towards homosexuals and same-sex affection "can be interpreted as political objection to the visibility of such minorities, associated to conservative dispositions towards sexual moral" (NATIVIDADE, Marcelo; OLIVEIRA, Leandro de. As novas guerras sexuais: diferença, poder religioso e identidades LGBT no Brasil. Rio de Janeiro: Garamond, 2013, p. 78).

11 BORRILlO, Daniel. Homofobia: história e crítica de um preconceito. Belo Horizonte: Autêntica, 2010. p. 34.
} 
orientation. ${ }^{12}$ Developed to the only standard, heterosexuality became compulsory and every other way of living that distances itself from this ideal is devalued. Also, heterosexuality is seen as the natural, correct, and healthy archetype while deviation is labeled as anti-natural, pathological, or sinful.

The above-mentioned definition by Borrillo shows the relation that exists between homophobia and discrimination against women as both are related to patriarchy and male domination, which imposes distinct, rigid, and unequal social roles to men and women justified through their naturalness and inevitability ("sexual differentialism") and male superiority in relation to the female. ${ }^{13}$

In this way homosexuality clashes with this hegemonic model through challenging gender performance in various levels like, e.g., in the sexual roles, since homosexuality is capable of making men take a passive posture which is destined for women; and that women take an active posture, reserved for men..$^{14}$ Thus, if the traditional construct of masculinity and femininity works through the unmoving separation of both universes, opposite and mirrored, the homosexual experience produces a disarrange in these frontiers ${ }^{15}$, which homophobia aims to reestablish and reinforce at every moment. ${ }^{16}$ Indeed, homophobia acts as a defense mechanism of the hegemonic model that pretends

12 Thus, "in the heterosexist ideology and system, more than a question of preference or sexual orientation, the binomial heterosexuality/homosexuality is a distinctive criteria to the recognition of dignity and the distribution of social, political, and economic benefits. (RIOS, R. R. "O conceito de homofobia na perspectiva dos direitos humanos e no contexto dos estudos sobre preconceito e discriminação". Op. Cit, p. 121).

13 Ibidem, p. 122. On the theme, Eribon argues the male domination should be understood in an ample manner, "as the domination of the 'masculine principle' over the 'feminine principle' and, thus, of the heterosexual man (i.e., the man!) over the homosexual man (that is not considered a man), in the sense that homosexuality is classified in the unconscious of our societies besides the "feminine"' (ERIBON, Didier. Reflexões sobre a questão gay. Rio de Janeiro: Companhia de Freud, 2008, p. 101)

14 In this sense, Miskolci differentiates homophobia and heteronormativity to argue that this would be the hegemonic sexual order and gender roles, and could be reproduced by samesex couples by emulation of traditional behavior and act in the erasing of the deviant gender experiences. Thus, the homosexual experiences would be submitted to distinct levels of social stigma depending on their distance from the hegemonic standard of gender experiences and family recommended by the heteronormative order. (MISKOLCI, Richard. Teoria Queer: um aprendizado pelas diferenças. $2^{\text {a }}$ Ed. Belo Horizonte: Autêntica, 2015, p. 15).

15 It is not a coincidence that homosexuality was perceived in the medical discourse in the end of the XIX century as a matter of "gender inversion", and that the homosexual male as someone who renounced their masculinity, such as the lesbian renounced their femininity. (ERIBON, D. Reflexões sobre a questão gay. Op. Cit., pp. 101-102).

16 WELZER-LANG, Daniel. "A Construção do Masculino: dominação das mulheres e homofobia". Estudos Feministas. Florianópolis, v. 9, n.2, 2001, p. 465. 
there is a linearity between sex, gender, and sexual desire/orientation, establishing as legitimate only those gender experiences that are "in accordance" with the "natural" sex of the individual and the sexual orientations that are aimed at the opposite sex/gender. ${ }^{17}$

According to Judith Butler, this coherence and continuity between sex, gender, sexual practice, and desire produces "intelligible" genders which are culturally acceptable and, from a causal relation between these elements (e.g., if male, then masculine), turn those who do not conform to this framing to unintelligible. ${ }^{18}$ For the author:

The heterosexualization of desire requires and institutes the production of discriminate and asymmetrical oppositions between 'feminine" and 'masculine', in which these are understood as expressive attributes of 'male' and 'female'. The cultural matrix through which gender identity is intelligible requires that certain types of 'identity cannot exist - that is, those in which gender do not arise from their sex and those in which the practice of desire do not 'arise' neither from 'sex' nor from 'gender'. [...] Alas, from this field's point of view, certain types of 'gender identity' appear as mere failures of development or logical impossibilities, precisely due to their non-conformity to the cultural intelligibility norms. ${ }^{19}$

Berenice Bento highlights this complementary and feedback relation between heterosexuality and gender binarism since the dichotomist and complementary model of gender-sex justifies heterosexuality as a natural and unquestionable standard at the same time that the discipline of gender performances in accordance to

17 On this linearity, Zambrano and Heilborn argue that "the common sense considers a person, classified as man or woman (biological sex) will naturally have the expected behavior to each of these possibilities (male or female gender identity/role), and that their sexual desires will be directed towards persons of the sex/gender that is differente from their own (heterosexual orientation). These three elements - sex, gender, orientation - are seen in our culture as always combined in the same way, that is, it creates an hegemonic standard of being a heterosexual masculine man or a feminine woman." (ZAMBRANO, Elizabeth; HEILBORN, Maria Luiza. "Identidade de gênero". In: LIMA, Antonio Carlos de Souza (coord.). Antropologia \& Direito: temas antropológicos para estudos jurídicos. Rio de Janeiro/Brasília: Contra Capa, 2012, p. 415).

18 BUTLER, Judith. Problemas de Gênero: feminismo e subversão da identidade. $8^{\text {a }}$ Ed. Rio de Janeiro: Civilização Brasileira, 2015, p. 43.

19 Ibidem, p. 44 
this single model would serve as control of the sexual deviations. ${ }^{20}$ According to Borillo, the binary division of gender and heterosexual desire are mechanisms of reproduction of the social order, not only of biological reproduction of the human species. Thus, the point of view in which homophobia is the 'guardian of the frontiers both sexual (hetero/ homo) and gender (masculine/feminine) ${ }^{21}$

In this way, the confrontation against the discrimination withstood by women and homosexuals would involve the same "common enemy" that historically approached the demands of both the feminist and LGBT movements. Both movements aim at the "politicization of everyday" and the "publicization of the private"22, and open the debate about the rigid separation of masculine and feminine gender roles, be it in the scope of family, be it in other social spaces, as well as a profoundly sexist and patriarchal culture that positions men and masculinity/virility as superior to women and femininity. According to Castells, the LGBT movement puts in risk patriarchy as it clashes with its premises of "compulsory heterosexuality" and "sexual repression", about which a rigid and hierarchical division of gender and sex roles has been historically established..$^{23}$

These structures of sexual repression and compulsory heterosexuality that the author mentions receive influx in Brazil -- and Latin America in general -- of the Christian formation of our cultural matrix and the persistent influence of the Catholic Church and the Christian worldview in politics. In this way, the hegemonic family model, not only heterosexual ("God made male and female") but also matrimonial, indissoluble, and profoundly patriarchal, corresponds to the standard model recommended by Catholicism, and that should be

20 BENTO, Berenice. "In school we learn that difference makes a difference". In: Estudos Feministas, 19(2), 2011, p. 553. In similar fashion, Butler proposes that "the institution of a compulsory and natural heterosexuality requires and regulates gender as a binary relation in which the masculine term differentiates itself from the feminine term, realizing this differentiation through the practices of heterosexual desire. The act of differentiating the two opposing moments of the binary structure results in a consolidation of each of their terms, of the internal coherence of sex, gender, and desire." (Butler, J. Problemas de Gênero. Op. Cit. p. 53)

21 BORRILLO, D. Homofobia. Op. Cit., p. 16.

22 Thus, "feminist theorists argue that 'the personal is political', meaning that the apparently 'natural' dominion of private intimacy (family and sexuality) is legally constructed, culturally defined, and constitutes a locus of power relations. In the majority of those, the emphasis was put on the critical deconstruction of private rhetoric as part of a domination discourse that legitimizes women oppression" (COHEN, Jean L. "Repensando a privacidade: autonomia, identidade e controvérsia sobre o aborto". In: Revista Brasileira de Ciência Política, $\mathrm{n}^{\circ} 7$. Brasília, janeiro/abril de 2012, p. 169).

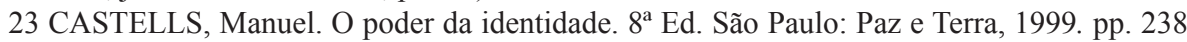
e 256. 
defended from the disruptive influences of feminism and the struggle of sexual minorities.

With all the above it is easy to notice that homophobia represents an inequality or injustice of cultural order. According to Nancy Fraser, injustices can have economic causes, which requires remedies based on redistribution policies; or cultural causes, which demands recognition policies for their confrontation. ${ }^{24}$ Fraser understands that, contrary to what happens with race and gender, ${ }^{25}$ injustice due to sexual orientation would be the archetype of a problem of recognition, stemming from "institutionalized standards of cultural value which construct heterosexuality as natural and normative and homosexuality as perverse

24 "Each dimension is associated to an analytically distinct dimension of injustice. In the recognition dimension [...] the associated injustice is the non-recognition, in which the standards of cultural value negate the necessary importance to participate entirely in the social life to some actors. For the distributive dimension, however, the injustice corresponds to the bad distribution, in which economic structures such as property regimes and job markets, private some actors of the necessary resources. Each dimension, finally, corresponds to an analytically distinct form of subordination. The recognition dimension corresponds, as we saw, to the status subordination rooted in institutional standards of cultural value. The distributive dimension, however, corresponds to economic subordination, rooted in structural characteristics of the economic system." (FRASER, Nancy. "Repensando a questão do reconhecimento: superar a substituição e a reificação na política cultural”. In: BALDI, César Augusto. (org.). Direitos Humanos na Sociedade Cosmopolita. Rio de Janeiro: Renovar, 2004, pp. 616-617). On the other hand, it should be highlighted that the author understands that it is possible that other forms of injustice exists, i.e., other forms of social order that produce other forms of subordination, highlighting that maybe the politic dimension could be a candidate to this tertium genus (FRASER, Nancy. "Social Justice in the Age of Identity Politics: Redistribution, Recognition, and Participation". In: FRASER, Nancy; HONNETH, Axel. Redistribution or Recognition?: a political-philosophical exchange. Londres: Verso, 2003. p. 68)

25 In spite of the elegance and didactic of this theoretical bipartition, the author advocates that the recognition and redistribution policies are not necessarily excluding, and that concrete injustices can assume both faces simultaneously, which she calls "bivalent collectivities", which would be the case of injustice by reason of gender or race. Thus, although some injustices are closer to one or the other extreme, concrete injustices can be arranged in a gradient between two poles of redistribution and recognition, requiring, for its coping, remedies of both types. (FRASER, Nancy. "Redistribuição, Reconhecimento e Participação: por uma Concepção Integrada de Justiça". In: SARMENTO, Daniel; IKAWA, Daniela; PIOVESAN, Flávia. (coords.). Igualdade, Diferença e Direitos Humanos. Rio de Janeiro: Lumen Juris, 2010, pp. pp. 171-178). The author defends, then, that the notion of "perspective dualism" understands that recognition and redistribution can be understood as "analytically distinct", not occupying concretely separate social spheres, in the sense that "distribution and recognition do not occupy separate spheres. Rather, they interpenetrate, to produce complex standards of subordination" (FRASER, Nancy “Distorted Beyond All Recognition: A rejoinder to Axel Honneth". FRASER, Nancy; HONNETH, Axel. Redistribution or Recognition?: a political-philosophical exchange. Londres: Verso, 2004, p. 217) 
and abject". ${ }^{26}$

According to the author, the recognition injustices are traditionally viewed as "identity distortions", based on the Hegelian notion that identity is build intersubjectively. ${ }^{27}$ The author, however, aims to discover an alternate model that views the misrecognition as a problem of "social status". ${ }^{28}$ According to this model, the institutionalized standards of cultural values should be analyzed by their effects on the relative position of social actors; it is, when these standards face the actors as equals, giving them the same value, one could talk of equality and reciprocal recognition, while different standards that seem the actors as inferior or superior, would cause exclusion and inequality, through status subordination and misrecognition. ${ }^{29}$

A central notion of Fraser's thought is that of participation parity, that requires of all members of society can interact between each other as free and equal partners, which in itself requires a distribution of material goods that would suffice (objective condition) and cultural standards of equal respect (intersubjective condition). ${ }^{30}$ It is based on this normative idea that the author justifies the duty of adopting redistribution and recognition policies. ${ }^{31}$ In this sense, the objective of recognition policies would be the participation parity on its intersubjective condition, that is, the construction of a world both tolerant and respectful towards difference, in which the assimilation of hegemonic cultural standards would not be a necessary price paid by minorities to enjoy their rights. ${ }^{32}$

\section{THE CONSTITUTIONAL DUTY OF FACING HOMOPHOBIA}

The duty of adopting recognition policies to face inequality stemming from cultural standards which produce subordination status - like homophobia - finds haven in the constitutional order of 1988. Academically it is discussed if the recognition in the constitutional field

26 "Institutionalized standards of cultural value construct heterosexuality as natural and normative, homosexuality as perverse and despised" (FRASER, N. "Social Justice in the Age of Identity Politics. p. 18). In spite of this, the author recognizes that redistribution issues can derive from these asymmetrical cultural standards. Thus, e.g., a person can be fired or impeded of having a social security benefit by reason of their sexual orientation. In this sense, recognition injustices can require, concretely, a redistribution policy, in a way that, from a practical standpoint every kind of subordination can be understood as two-dimensional. (Ibidem, pp. 24-25).

27 FRASER, N. "Repensando a questão do reconhecimento". Op. Cit, pp. 604 et seq.

28 Ibidem, pp. 610 et seq.

29 FRASER, N. "Social Justice in the Age of Identity Politics". Op. Cit.. pp. 29-30.

30 Ibidem. pp. 36-37.

31 FRASER, N. "Distorted Beyond All Recognition. Op. Cit, p. 217, p. 218.

32 Ibidem. p. 7. 
comes from the principle of the dignity of the human person ${ }^{33}$, from the principle of equality ${ }^{34}$, or the right of freedom ${ }^{35}$. Normative basis aside, the dimension of recognition of subjects has constitutional hierarchy as a fundamental right, which means the State must maintain it. Moreover, it dictates the State should adopt recognition policies aiming to transform reality, overcoming asymmetric and stigmatizing cultural standards ${ }^{36}$.

Starting from the principle of equality, Piovesan highlights that the constitutional order dictates equality not only in a negative dimension, as prohibition and repression of discrimination; but also, as a positive dimension that aims to promote the inclusion of stigmatized groups. According to the author, "prohibition of exclusion, in itself, does not automatically result in inclusion" 37 . As such, the constitutional order not only prohibits homophobic discrimination, from public or private agents, but also urges the adoption of vigorous and active measures for social transformation and overcoming a factual framework of intolerance and discrimination.

On the other hand, Sarmento arrives at the same conclusion facing recognition as a corollary of the dignity of the human person:

\begin{abstract}
It is possible to talk about a fundamental right to recognition, which is a right to the equal respect of personal identity. It is a right which has a negative and a positive aspect. In its negative aspect, it prohibits practices that disrespect people in their identity, stigmatizing them. In the positive dimension it mandates the State the adoption of measures aimed at facing these practices and the overcoming of existent stigma ${ }^{38}$.
\end{abstract}

Indeed, the 1988 Constitution goes way beyond the formal vision in relation to the role of the State towards inequality and discrimination. Article 3 defines programmatically as fundamental objectives of the Federative Republic of Brazil, among others, "to eradicate poverty and

33 SARMENTO, Daniel. Dignidade da Pessoa Humana: conteúdo, trajetórias e metodologia. Belo Horizonte: Fórum, 2016, pp. 255-257.

34 BARROSO, Luís Roberto; OSÓRIO, Aline Rezende Peres. "Sabe com quem está falando?": Algumas notas sobre o princípio da igualdade no Brasil contemporâneo. pp. 8 et seq. Disponível em: <http://www.luisrobertobarroso.com.br/wp-content/themes/LRB/pdf/ SELA_Yale_palestra_igualdade_versao_fina.pdf $>$. Acesso em: 21.04.2017.

35 LOPES, José Reinaldo de Lima. “O direito ao reconhecimento para gays e lésbicas”. In: Sur - Revista Internacional de Direitos Humanos, ano 2, Número 2, 2005, p. 86.

36 Ibidem, p. 82.

37 PIOVESAN, Flávia. Temas de Direitos Humanos. $3^{\text {a }}$ Ed. São Paulo: Saraiva, 2009, p. 189 38 SARMENTO, D. Dignidade da Pessoa Humana. Op. Cit, pp. 256-257. 
marginalization and reduce social and regional inequality" (subsection III) and "promote the good of all, without prejudice due to origin, race, sex, color, age, and any other form of discrimination" (subsection IV), while the preamble advocates the construction of "a fraternal society, plural and without prejudices". Thus, equality should be understood not only as a fundamental principle but also as a constitutional objective to be chased.

In this way, the constituent exhorts the State to act positively to deconstruct cultural standards which produce hierarchies and asymmetry. The constant use of action verbs to treat the theme reinforces the idea that the constituent did not resign when faced with the lack of equality of Brazilian society, crediting to the State a transformative and emancipator role which should be vigorously exercised ${ }^{39}$. In this scenario, the Brazilian State is seen as "an instrument to the ends of political community", among which it highlights "the promotion of effective and concrete equality". ${ }^{40}$

The explicit valorization of ethnical (blacks and Indians $)^{41}$ and gender (women) ${ }^{42}$ minorities in the constitutional system comes from the perception that historically stigmatized groups oftentimes are not adequately contemplated by generic enunciations, and also their importance in the formation of a plural and tolerant society. As such, the overcoming of cultural standards which produce recognition injustices relates to the so called right to difference, which means the symbolic valorization of difference, which mandates the State to a more acting and active posture, aiming to protect the manifestations of minorities facing homogenization, assimilation, prejudice, and excluding cultural standards. In this sense, the right to difference can be understood in this double function through the classic construction of Boaventura de Souza Santos:

\section{People have the right to be equal whenever}

39 SARMENTO, D. “A Igualdade Étnico-Racial no Direito Constitucional Brasileiro”. Op. Cit., p. 142.

40 CASTRO, Carlos Roberto Siqueira. "A nova dimensão da igualdade". In: CASTRO, Carlos Roberto Siqueira. Constituição Aberta e os Direitos Fundamentais: Ensaios sobre o constitucionalismo pós-moderno e comunitário. $2^{\mathrm{a}}$ Ed. Rio de Janeiro: Forense, 2010, p. 361. 41 Thus, e.g., the criminalization of racism (Article 5, XLII); the possibility of teaching in native languages (Article 210, §2); valorization and protection of native and Afro-Brazilian cultural manifestations (Article 215); protection of native customs and communities, especially in regards to land (Articles 231 and 232); valorization of the contribution of different cultures and ethnics in teaching Brazilian History (Article 242, §1); the recognition of the property of Quilombola communities (Article 68 of ADCT).

42 In this regard, e.g., specific protection in the job market (Article 7, XX), earlier age and less contribution time for retirement pension (Articles 40, III, and 201, §7), guarantee of equality in the family (Article 226, $\S 3$ and 5). 
difference makes them inferior, but they also have the right to be different whenever equality jeopardizes their identity. Thus, the necessity of an equality that recognizes the differences and a difference that does not produce, feeds, or reproduces inequality. ${ }^{43}$

Observing the right to difference often resignifies the difference, i.e. those stigmatizing and socially discredited attributes. Thus, if inequality in the field of recognition stems from the hierarch and homogenizing social representations of race/color, gender, sexuality, creeds etc., its facing requires the deconstruction of these negative representations through valorization and celebration of pluralism and diversity as a way to create an ethic of tolerance and auterity. Vianna affirms that:

Talking about a "right to difference" means, first, recognizing the possibility of cultural and social heterogeneity as legitimate in ample political universes, endowed with a supposed "unity" [...] More than apprehend the difference as an inherent condition to social groups, that equates to defend it as something relevant in the constitution of individual and collective specifics that do not wish to negate it to be recognized as legitimate participants of embracing unities. ${ }^{44}$

As exposed, it is possible to conclude that, if discrimination by reason of sexual orientation is rejected by the constitutional order, which imposes to the State not only a negative duty of prohibiting exclusion, a positive duty of inclusion, the State has the duty of adopting recognition policies as a means of deconstructing social standards that produce homophobia as analyzed in the previous section. Thus, if homophobia stems from a system that hierarchs the distinct sexual orientations, choosing heterosexuality as the single standard, the right to difference struggles for the adoption of recognition policies that values other possible forms of experiencing sexuality, defending their legitimacy. Equally, if homophobia derives from a model of exclusive gender experiences, it is necessary to adopt measures that clash with this model.

43 SANTOS, Boaventura de Sousa. Reconhecer para Libertar: Os caminhos do cosmopolitismo multicultural. Rio de Janeiro: Civilização Brasileira, 2003, p. 56.

44 VIANNA, Adriana de Resende Barreto. "Direito à Diferença: introdução". In: LIMA, Antonio Carlos de Souza (coord.). Antropologia \& Direito: temas antropológicos para estudos jurídicos. Rio de Janeiro/Brasília: Contra Capa, 2012, p 205. 
On the other hand, the notion of recognition policies must be understood in an embracing form, grouping an infinity of possible measures for the facing of cultural injustice situations. Thus, e.g., the formal guarantee of equal rights to the same sex marriages in relation to families formed by men and women is probably the most visible recognition policy in the field of homosexual rights and a measure that has considerable potential of clashing with homophobia, questioning the gender preconceptions and familiar model that feed it and allowing people to abandon their prejudices and preconceptions towards homosexuality through living with families formed by two men or two women. From this notion, the next section will analyze one of the possible fields for these policies.

\section{SCHOOLASAPRIVILEGED SPACE TOFACE HOMOPHOBIA}

As we saw, the recognition policies should be understood as measures that aim to question a certain sociocultural reality and act towards its transformation, aiming to make it more plural, tolerant, and emancipated. Also, the adoption of such measures by the State is a constitutional duty. In this framework, school and education have a central role for two related reasons. First due to the major role they maintain in the production and reinforcement of asymmetric cultural standards and, in this sense, in the reality one aims to modify. ${ }^{45}$ Thus, as will be demonstrated, schools are spaces for normalization and production of homophobia's cultural basis. On the other hand, education also maintains a highlighted potential in intervening in this reality which it helps build, and can be a space for overcoming homophobia, not reinforcing it. ${ }^{46}$ This situation is portrayed by Debora Diniz and Tatiana Lionço:

In schools, aside from the formal transmission of knowledge, public spaces for the promotion of citizenship and the exercise of human rights are born. In this sense, the school is a space that allows

45 According to Junqueira, "the field of education constitutes itself historically as a discplinating, normalizing, and inequality reproducing space" (JUNQUEIRA, Rogério Diniz. "Políticas de educação para a diversidade sexual: escola como lugar de direitos. In: LIONÇO, Tatiana; DINIZ, Debora. (Orgs.). Homofobia \& Educação: um desafio ao silêncio. Brasília: LetrasLivres, EdUnB, 2009, p. 162). In similar fashion, Nancy Fraser points that value standards that impede participation parity continue to regulate the most important interactions in social institutions such as education. (FRASER, N. "Social Justice in the Age of Identity Politics". Op. Cit.. p. 57). 46 SOUZA, Elizeu Clementino de. "Direitos humanos e diversidade sexual na escola: homofobia, trabalho docente e cotidiano escolar". Conjectura: filosofia e educação; v. $20, \mathrm{n}^{\circ}$ especial, 2015, p. 200. 
for the representation of social reality in its diversity, which can be an emancipator tool. However, through the practices and content, this same space can be taken by discrimination, in a dynamic that values difference in a way that produces inequality and injury to the discredited parts. ${ }^{47}$

Analyzing in which way schools act reinforcing homophobia, it should be highlighted that the school is a space of heightened construction of a general notion of the world, acting in the reproduction of notions espoused by male domination and gender role stratification, in relation to "natural differences" between genders, and male superiority. Thus, e.g., its common to resort - and, in this way, reinforcing and naturalizing - to gender division in the school ambiance in various level: from the organizational level (e.g., "boys queue and girls queue"); activities (e.g. in the division of sports for physical education); uniforms etc. ${ }^{48}$. Unsurprisingly, these same establishments were historically segregated based on the binary gender division, with institutions being exclusively male or female ${ }^{49}$. Moreover, the reinforcement of gender roles in the school ambiance occurs in a subtler - although still powerful - manner, from, e.g., the expectations of activity, agitation and dynamism linked to boy's virility in opposition to the "good behavior" or "grace" of girls (e.g. "girl's handwriting"), which puts more energetic girls and more introverted boys as gender deviants ${ }^{50}$.

Therefore, Miskolci argues that education and school have an important role in the production, reproduction, and reinforcement of gender norms "aimed to the construction of ideal men and women, it is: 'normal', 'correct', people as our society makes us believe we should be". ${ }^{51}$ Equally, Junqueira understands school as an "obstinate space

47 DINIZ, Debora; LIONÇO, Tatiana. "Educação, direitos sexuais, laicidade e diversidade sexual". In: RIOS, Roger Raupp; GOLIN, Célio; LEIVAS, Paulo Gilberto Cogo. Homossexualidade e Direitos Sexuais: reflexões a partir da decisão do STF. Porto Alegre: Sulina, 2011, p. 125.

48 LINS, Beatriz Accioly; MACHADO, Bernardo Fonseca; ESCOURA, Michele. Diferentes, não Desiguais: a questão de gênero na escola. São Paulo: Reviravolta, 2016,p. 9; JUNQUEIRA, Rogério Diniz. "Pedagogia do armário e currículo em ação: heteronormatividade, heterossexismo e homofobia no cotidiano escolar". In: MISKOLCI, Richard; PELÚCIO, Larissa (orgs.). Discursos fora da ordem: sexualidades, saberes e direitos. São Paulo: Annablume, Fapesp, 2012, pp. 288-289.

49 On the other hand, in spite of the new constitutional order - and even the march of history at least one example of an institution only for boys still resists in brazil: Colégio São Bento, in Rio de Janeiro.

50 LINS, B. A.; MACHADO, B. F.; ESCOURA, M. Diferentes, não Desiguais. Op. Cit., pp. 22-23.

51 MISKOLCI, R. Teoria Queer. Op. Cit., p. 12. 
in the production, reproduction, and actualization heteronormativity parameters" and "as an institution fiercely working in the reaffirmation and guaranteeing the success of the processes of compulsory heterosexualization as well as the incorporation of gender norms" The guaranteeing of this normalizing function stems not only from the rigidly genderized organization, but also the rigid means of control, vigilance, and disciplinary correction of the bodies and subjects in formation.

It is no accident that the school experience is usually traumatic for people whose identities or experiences clash with traditional and hegemonic expectations of gender performance of sexuality. Thus, transvestites and transsexuals have high school evasion numbers due to factors ranging from physical and moral violence perpetrated by colleagues, to institutional violence due to the imposition in the use of restrooms, uniforms, and name not conforming to the person's identity ${ }^{53}$.

In general, the content of sexual diversity is absent in the institutional preoccupations of schools and curricula. The theme of sexuality usually appears in class under the lens of social control and danger, and not valorization. Thus, the treatment given only in biology or general science class ignores the social and historical content of sexuality, usually relegating the theme to reproduction/contraception (turning non-reproductive sexual practices invisible) or STDs (creating a hygienist discourse of sexual repression) ${ }^{54}$. It is not a matter of defending that these themes are unimportant, but the perception that "reducing sexuality, desire, and pleasure to public health imperatives can be a form of violence in relation to the different individual aspirations" 55 . In this way, the treatment of sexuality in class turns homosexuality invisible in the same way it elects reproductive heterosexuality (penisvagina) as the only healthy experience ${ }^{56}$.

52 JUNQUEIRA, R. D. "Pedagogia do armário e currículo em ação". Op. Cit., p. 281.

53 PERES, William Siqueira. "Cenas de exclusões anunciadas: travestis, transexuais e transgêneros e a escola brasileira”. In: JUNQUEIRA, Rogério D. (Org.). Diversidade Sexual na Educação. MEC/Unesco, 2009. Bento criticizes the use of the term "evasion" in this context, using "expulsion" since there is a will to eliminate the subjects that "contaminate" the school ambiance (BENTO, B. "Na escola se aprende que a diferença faz a diferença". Op. Cit., p. 555). 54 According to Diniz and Lionço: "heteronormativity is founded upon the discourse on human biology, in a way to naturalize the bodies and sexual relation. There is no reference to the social and simbolic dimension of sexuality, being the sexual reproduction the standard of discussions in textbooks of junior high and high school" (LIONÇO, Tatiana; DINIZ, Debora. "Homofobia, silêncio e naturalização: por uma narrativa da diversidade sexual". In: LIONÇO, Tatiana; DINIZ, Debora. (Orgs.). Homofobia \& Educação: um desafio ao silêncio. Brasília: LetrasLivres, EdUnB, 2009, p. 54).

55 MISKOLCI, R. Teoria Queer. Op. Cit, pp. 47-48

56 ALMEIDA, Edson Leandro de. Escola sem Homofobia: a (re)produção da identidade sexual nos discursos escolares. (Dissertação de Mestrado). Programa de Pós-Graduação em Educação, 
If in the field of formal curriculum we observe the absence and invisibility of debates around sexual diversity, in the scope of the so called "occult curriculum" of schools there is a clear reproduction and reinforcement of homophobia. ${ }^{57}$ The process of normalization often happens in this "informal" curricular sphere - albeit due to complacency of the formal/official instances - that teach those that deviate from what is considered "normal", usually in a painful way, their place in the world. If, as Eribon shows, abuse is central in the homosexual subjectivation ${ }^{58}$, the school experience takes a crucial role in this process. Not coincidentally, Junqueira affirms the existence in schools of a "insult pedagogy", formed by a myriad of violences and dehumanizations, that produces a "closet pedagogy", understood as a tool of silencing and invisibilization ". An important part of this "occult curriculum" is bullying exercised by students - although not only by them - against other students considered gender deviants, especially boys. The construction of masculine subjectivation is in great measure formed from the denial of the feminine, and the violence against a feminine colleague ("viadinho") is a way for boys to reaffirm their own virility. ${ }^{60}$

On the other hand, although many times it acts in the reinforcement of an unequal reality, as seen, the school can also be a valorous agent in the transformation and emancipation of said reality.

Culturas e Identidades. Universidade Federal Rural de Pernambuco, Recife, 2016, p. 48. On the theme of sexual education, Elizeu de Souza points that: "it is based on matrimony as an apex of sexual expression, that school propagates sexual values through the control and 'biologization' of sexuality of subjects with self-repression, culpability, as opposed to pleasure, thus negating homosexuality as expression of the difference that does not conform to the standards of 'normality'. The 'de-sexualization' of subjects comes culturally marked by biologization and different concepts and moral councils that relate to sexuality, locking it to procreation and maintenance of the species. Emptying sexuality of its core content - pleasure - is the basic duty adopted by school through the so called 'sexual education'. [...] The negation of the idea of pleasure, transposed by duty in the conservative society, characterizes itself with sacrifice, obedience, discipline, punishment, and resignation of moral and sexual conducts and postures of the subjects." (SOUZA, E. C. "Direitos humanos e diversidade sexual na escola". Op. Cit., p. 217).

57 The notion of occult curriculum embraces all the aspects of the school ambiance that, without being a part of the official, explicit curriculum, contribute to the relevant social learning. Thus, e.g., the relation between student and tacher, between students, the organization of school space, the disciplinary norms, etc. (JUNQUEIRA, R. D. "Pedagogia do armário e currículo em ação". Op. Cit, pp. 277-278)

58 ERIBON, D. Reflexões sobre a questão gay. Op. Cit., pp. 27-29.

59 JUNQUEIRA, R. D. "Pedagogia do armário e currículo em ação". Op. Cit, pp. 284-287.

60 BARRETO, Ana Luiza Cruz Sá. A escola e o seu papel na construção de diferentes identidades sociais. (Dissertação de Mestrado). Curso de Mestrado em Psicologia. Centro Universitário de Brasília, Brasília, 2016, p. 99. 
It means to say "this same school that everyday cultivates and teaches prejudice and discrimination is also a privileged space for the critique and problematization of reification and marginalization mechanism and dehumanizing beliefs and attitudes" ${ }^{91}$. Said in another way, it is possible to conceive a more tolerant, democratic, and plural school, in which the educational practice - be it through formal curriculum, be it through hidden components of the occult curriculum - would be in consonance with the duties posited in the 1988 constitutional order in regard to recognition policies.

It is important to highlight that the Constitution establishes in Article 205 that the objective of education is - in this order - the "full development of the person, its preparation for the exercise of citizenship and its qualification for work". In the same way, the Law for Directives and Basis of Education (Law n. 9.394/96), although silent in regard to sexual diversity, proposes an education aimed towards tolerance, pluralism, ethical formation, and human solidarity of students. It means that more than a mere technocratic instance of content apprehension of the formal curriculum, the school is understood in the Brazilian legal order as a central space in the construction of citizenship and the development of individual capacities. A school that is not dedicated to the practice of tolerance and valorization of pluralism is subverting these commands, frustrating, e.g., the development of individual capacities in the students submitted to the "insult pedagogy" and the "closet pedagogy" 62 .

Thus, some measures can be taken to transform the school's role. First, one that regards the inclusion in the formal curriculum of debates about sexual diversity, raising awareness of students about the theme and promoting a culture of tolerance ${ }^{63}$. In this sense, ending the monopoly of biology over the discussion of sexuality, discussing the theme in a interdisciplinary manner - or at least facing the current heteronormative-reproductive paradigm of sexual education - can help in denaturalizing heterosexuality as the only legitimate model for sexuality. An important question is in regard to the preoccupation of the theme of sexual diversity used in the pedagogic material in class. Analyzing the textbooks chosen for the "Programa Nacional do Livro Didático", Lionço and Diniz point to a scenario not only of absence

61 JUNQUEIRA, R. D. "Pedagogia do armário e currículo em ação”. Op. Cit,, p. 279.

62 TEIXEIRA, Adla Betsaida Martins; FREITAS, Marcel de Almeida. "Homofobia e misoginia na escola: enfrentamento a partir dos direitos humanos". In: Teoria \& Sociedade, n 21.2, 2013, p. 293.

63 An interesting precedent in the Brazilian legal order was the inclusion through laws $n^{\circ}$ $10.630 / 03$ and $11.645 / 08$ of the compulsory teaching of Afro-Brazilian and native culture and history in an interdisciplinary manner, in a recognition policy that aims to deconstruct an Eurocentric worldview. 
of the them, but also the relevant reinforcement of heteronormativity of social relations and the reduction of sexuality to its biologic and reproductive component ${ }^{64}$. Still about the textbook issue, Rios e Santos point that, although the directives of the Ministry of Education were successful in eliminating explicit stereotypes and prejudices from the textbooks chosen in the scope of the national program, they were not able to effectively insert in its pages a propositional discussion about the recognition of sexual diversity ${ }^{65}$. Due to this silencing, the debates about homophobia and sexual diversity only occur due to the initiative of educators interested in the subject.

Another essential measure related to the above is related to the necessity of policies aimed at the formation of teachers specifically in regard to the overcoming of homophobia as "normal" practice in school everyday life ${ }^{66}$. These policies should, first, aim at raising awareness in educators about sexual diversity and the incentive for debating it in the classroom, approaching sexuality beyond the biologizing and normalizing perspective and valorizing an interdisciplinary approach, as a means to promote a more inclusive and tolerating education ${ }^{67}$. On the other hand, these education professionals should also be prepared to recognize and intervene in homophobia situations. Indeed, the "insult pedagogy" often has the condescension and even complicity from the institution; teachers and directors ignore homophobic bullying or, when violence is impossible to ignore, promote victim blaming ${ }^{68}$.

64 LIONÇO, T.; DINIZ, D. "Homofobia, silêncio e naturalização". Op. Cit., pp. 52-53. Due to a series of factors that will be better explained in the next section, even the treatment of sexuality in the usual frames can be a hard subject, as a recent episode in which a group of parents of students of a municipal school in Ji-Pará, Rondônia, made a public petition trying to take away a science textbook that showed a drawing of an erect penis shows. About this case, see the reflections of Eliane Brum: (BRUM, Eliane. "Escola Sem Pinto". El País. Opinião. Publicado em 17.04.2017. Disponível em <http://brasil.elpais.com/brasil/2017/04/17/ opinion/1492435392_872941.html>. Acesso em 21.04.2017).

65 RIOS, Roger Raupp; SANTOS, Wederson Ruffino dos. "Diversidade sexual, educação e sociedade: reflexões a partir do Programa Nacional do Livro DidáticoIn: LIONÇO, Tatiana; DINIZ, Debora. (Orgs.). Homofobia \& Educação: um desafio ao silêncio. Brasília: LetrasLivres, EdUnB, 2009, p. 147.

66 SOUZA, E. C. "Direitos humanos e diversidade sexual na escola". Op. Cit., p. 206; ALMEIDA, E. L. Escola sem Homofobia. Op. Cit., p. 49.

67 About this theme, the Juvenile Statute (Law n. 12.852/2012), one of the few laws in the Brazilian legal order that expressly talk about sexual orientation, recommends in its Article 17, II that among the policies that should be adopted by the State in "effecting the right of the young to diversity and equality", the "inclusion of themes about ethnic, racial, handcap, sexual orientation, gender, and sexual and domestic violence against women in the formation of education professionals".

68 RIOS, R. R.; SANTOS, W. R. "Diversidade sexual, educação e sociedade". Op. Cit., p. 144; TEIXEIRA, A. B. M.; FREITAS, M. A. "Homofobia e misoginia na escola". Op. Cit., p. 298; 
Finally, a revision of the school structure, highly gendered, could take students to question their own stratification of gender roles beyond the school walls. Thus, e.g., it is possible to avoid the organizational resource of division between "boys" and "girls", making the same activities available to all students, respecting the gender identity of the students in the access to the facilities and in the choosing of the uniform ${ }^{69}$, among other. In this sense, the teachers and education professionals in general have a fundamental role in the construction and maintenance of such a stratified and stereotyped gender structure in the school ambiance ${ }^{70}$, an issue to be addressed by the formation programs.

The main federal public policy towards recognition in this issue was the project "Escola sem Homofobia", launched in 2011, that had as an objective putting in effect the actions posited in the "Brasil sem Homofobia" program, from $2004^{71}$. The project had actions from various Ministries, mainly Health and Education, and had the participation of representatives from society and academia ${ }^{72}$. Although it encompassed various initiatives ${ }^{73}$, the policy became famous due to the "kit" of printed and audiovisual materials that incentivized the debate about sexual diversity and gender identity with students from junior high to high school, through the mediation of teachers and schools ${ }^{74}$. Such a "kit", however, was vetoed and recalled by the Presidency after it was questioned by conservative politicians, as will be approached in the next section.

According to Nancy Fraser, the recognition and redistribution remedies that aim towards facing the respective injustices can be based in affirmative and transformative strategies. The remedies based on

BARRETO, A. L. C. S. A escola e o seu papel na construção de diferentes identidades sociais. Op. Cit., p. 101.

69 Recently Colégio Pedro II, in Rio de Janeiro, ended the traditional gender divide of the uniform - pants for boys and skirts for girls - in a way that students can now choose which piece of clothing better fits their gender identity.

70 SOUZA, E. C. "Direitos humanos e diversidade sexual na escola”. Op. Cit., p. 205.

71 The "Brasil sem Homofobia" program included an array of policies and initiatives, organized in eleven thematic axis, including a specific one on right to education (CONSELHO Nacional de Combate à Discriminação. Brasil Sem Homofobia: Programa de combate à violência e à discriminação contra GLTB e promoção da cidadania homossexual. Brasília: Ministério da Saúde, 2004, pp. 22-23. Disponível em: <http://bvsms.saude.gov.br/bvs/publicacoes/brasil_ sem_homofobia.pdf $>$. Acesso em: 21.04.2017).

72 ALMEIDA, E. L. Escola sem Homofobia. Op. Cit., pp. 57-58.

73 A relevant initiative was the training of education professionals, that acted as propagators of the public policy in their own schools. Six rounds of training were made with about 200 professionals (VITAL, Christina; LOPES, Paulo Victor Leite. Religião e Política: uma análise da atuação dos parlamentares evangélicos sobre direitos das mulheres e de LGBTs no Brasil. Rio de Janeiro: Fundação Heinrich Böll, 2012, p. 203).

74 Ibidem, pp. 110-111 e 200-203. 
affirmative strategies aim to correct injustices stemming from social arrangements without modifying the structures that produce them, while transformative strategies aim to transform the deep social structures producing injustice. The author understands that transformative policies are preferable to the mere affirmative, although they are harder to implement in practice ${ }^{75}$. In this sense, Fraser defends that the middle road of "non-reformist reform", which would be apparently affirmative measures that, accumulated and through time, have the potential of generating transformative effects ${ }^{76}$.

According to this classification, it is possible to notice that school and education have a transformative potential capable of questioning the basis in which homophobia structures itself. The distinct, concrete mechanisms suggested, like the inclusion of the theme of sexual diversity in the official curriculum or the "degenderification" of the school ambiance, have at least the capacity of promoting a "nonreformist reform". The intervention on education, privileged space of subjectivation and construction of citizenship and social norms, has a remedial capacity of the cultural inequalities that goes way beyond that of mere affirmative. It is for this reason that we affirm that school is a privileged space for facing homophobia.

Facing this frame, the prevalence that criminalization has acquired in the organized LGBT movement as the main standard of combating homophobia should be criticized. The appeal to penal law, sometimes seem as a panacea even when faced with extremely complex social realities, is seem with reservations by some sectors of the militants, from the critique of creation of new penal types and the bloating of the Penal State ${ }^{77}$, in itself a producer of inequality; and the idea that other mechanisms - such as education - would be more effective in facing and deconstructing prejudice ${ }^{78}$. Thus, Borrillo understands that prior

75 FRASER, N. "Social Justice in the Age of Identity Politics. pp. 74-78.

76 Ibidem. pp. 79-80.

77 AGUIÃO, Silvia; VIANNA, Adriana; GUTTERRES, Anelise. "Limites, espaços e estratégias de participação do movimento LGBT nas políticas governamentais". In: LOPES, José Sergio Leite; HEREDIA, Beatriz (orgs.). Movimentos Sociais e Esfera Pública: o mundo da participação. Rio de Janeiro, CBAE, 2014, p. 253. On the other hand, Vecchiatti, one of the main advocates for homophobia criminalization, denounces these discourses as "selective penal minimalism", that only happens for the protection of LGBT people, resulting in a "hierarchy of oppressions" in relation to other stigmatized groups already contemplated by the penal law (VECCHIATTI, Paulo Roberto Iotti. "Fundamentos em prol da Criminalização da Homofobia e da Transfobia”. Jota. Publicado em 07.07.2016. Disponível em $<$ https://jota.info/ artigos/fundamentos-em-prol-da-criminalizacao-da-homofobia-e-da-transfobia-07072016>. Acesso em 21.04.2017)

78 . For example, Jean Wyllys: "I believe that it is not only through penal law that we will erradicate homophobia and I believe that the strengthening of the Penal State, including these cases, is not a good idea [...] We need programs against bullying in schools, national campaigns 
to repressing homophobia a pedagogic-preventive action that modifies the way through which sexual diversity is socially seem is necessary, without which criminalization would be senseless ${ }^{79}$. In addition, in Fraser's proposed taxonomy it seems evident that criminalization is a mere affirmative answer to the issue of homophobia, since it does not deconstruct the structures that produce it, only intervening ex post facto in a situation of manifest discrimination.

\section{DISPUTES AND TENSIONS}

In spite of the constitutional exhortation of State intervention for the transformation of social reality aiming for the deconstruction of the social and cultural standards that produce homophobia, and the preponderance that education and school take in this frame, such confrontation finds significant resistance of conservative forces for the maintenance of the status quo. These agents dispute constitutional meanings in the defense of a moral agenda that aims at the reinforcement, and not deconstruction, of such standards.

The banner of "defense of the family" is the rhetorical umbrella under which most items of the conservative agenda are included, such as women's and LGBT rights and drug legalization. What this banner intends is, actually, the defense of a single and exclusive conception of family as "natural" or morally acceptable. This traditional model of family is that marked by stratification of gender roles and hierarchy of sexual experiences responsible for the production of homophobia. This agenda of "sexual moralism" in politics is claimed by the religious agents, especially Catholics and evangelicals.

The influence of religion in the national politic debate, although not a new process, has gained more importance since the $1990 \mathrm{~s}$ with the occupation of legislative seats by religious people linked to Christian churches, especially neo-Pentecostals ${ }^{80}$. These parliament members have an agenda based on the "defense of the family" and a high organizational capacity, forming a cohesive bloc structured in the

against prejudice, public investment favoring diversity, a law that allows people to defend themselves against discrimination in the workplace, on the access of public services, and other matters of social life. We need, finally, of strong and decisive action of the State in the sense of eradicating the homophobic violence and all forms of legal discrimination that legitimize it" (WYLLYS, Jean. Tempo Bom, Tempo Ruim: identidades, políticas e afetos. São Paulo: Paralela, 2014, pp. 81-82).

79 BORRILLO, D. Homofobia. Op. Cit. p. 106.

80 MIGUEL, Luis Felipe. 'Da 'doutrinação marxista' à 'ideologia de gênero': Escola sem Partido e as leis de mordaça no parlamento brasileiro”. In: Direito \& Práxis. Rio de Janeiro, Vol. 07, $\mathrm{n}^{\mathrm{o}}$ 15, 2016, p. 593. Vital and Lopes call this process "confessionalization of politics" (VITAL, C.; LOPES, P. V. L. Religião e Política. Op. Cit., p. 171). 
form of a parliament front, called "bancada evangélica" "1. Presenting themselves as an expressive group in the National Congress, these parliament members linked directly to religions have a huge capacity of negotiating the formulation of federal public policy in the Brazilian system of "coalition presidentialism"

Facing this framework, education public policies have a central role in the "defense of the family" political groups preoccupations, due to a series of factors, e.g., the effective capacity of recognition policies in this area undermine their foundations, as previously shown. Moreover, before the sex and specifically the juvenile sexuality taboo, denouncing the insertion of sexuality in the school universe can trigger moral panic and, in this way, be politically and electorally advantageous. The definition the contours between education and religious visions is in itself one of the hardest points of tension with the principle of secularism to equate in the 1988 Constitution, that expressly provides the duty of providing religious education, albeit optional, in Article 210, $\S 1^{083}$.

One of the more expressive exhibition of political force of the "bancada evangélica" involved an education public policy for the struggle against homophobia. It is about the suspension of the courseware from the "Escola Sem Homofobia" project in 2011 by the Federal Government, commonly referred to as "kit gay" by its detractors. After intense pressure from religious sectors and extreme right-wing parliament members that threatened to call then-Secretary of State Antonio Palocci to explain to Congress his contested patrimonial evolution, President Dilma Rousseff suspended the project with the argument that the government would not make "propaganda about

81 Ibidem, pp. 156 seq.

82 Ibidem, p. 9. The idea of a "coalition presidentialism" aims to portray the Brazilian political model, in which there is ample fragmentation of power in the Legislative branch, due to party pulverization. This circumstance requires that the Executive branch make alliances with diverse political groups to form a parliament majority and approve laws and constitutional amendments of its interest, forming a foundation that is ideologically heterogenic, which would produce instability and internal disputes. Thus, e.g., the worker's party governments, although viewed as left-wing or center-left, had alliances with right-wing or center-right parties, such as PR, PP and PSC, for governability.

83 Although the provision is complemented by Article 33 of the Lei de Diretrizes e Bases (Law n. 9.304/96), the specific way in which the constitutional norm must be concretized is object of an intense debate in the scope of law, waiting a decision by STF on the ADI n. 4.439. On the theme, see: DINIZ, D.; LIONÇO, T. "Educação, direitos sexuais, laicidade e diversidade sexual”. Op. Cit.; PEREIRA, Jane Reis Gonçalves. "A aplicação de regras religiosas de acordo com a lei do Estado: um panorama do caso brasileiro". In: Revista da $A G U$, v. 41, 2014, pp. 20 et seq. e SARMENTO, Daniel. "Ensino religioso nas escolas públicas". Jota. Publicado em 23.06.2015. Disponível em<https://jota.info/artigos/ensino-religioso-nas-escolas-publicas-23062015>. Acesso em 21.04.2017. 
sexuality choices" $"$.

The main rhetorical artifact of this religious conservationism in the field of education was the creation of the notion of "gender ideology", an idea that got traction during the long debate to approve the new Plano Nacional de Educação - PNE (Law n ${ }^{\circ} 13.005 / 2014$ ), and state and city plans later ${ }^{85}$. From a skewed, simplifying, or even caricatural vision from the discussions of feminism and queer theory ${ }^{86}$ they defend that the discussion of gender as cultural production represents a subversion of natural sexuality and families, acting in defense of dominant sex and family understandings, with an essentialist and biologizing discourse ${ }^{87}$. In this sense, religious and pseudo-scientific arguments about sexuality are lapped together, from the idea that healthy behavior can only be possible in a heterosexual and Christian family, while deviant forms of sexuality are framed as sinful, anti-natural, and pathological. To its detractors, the so-called "gender ideology" represents a "unique, indistinct threat of subversion to the family arrangements that are seen as natural, divine, and indispensable to social life reproduction" $" 88$. Moreover, through the triggering of moral panic about child sexuality, they defend that children and teenagers would be more vulnerable to such an insidious influence, thus giving centrality to the debate in education. Another strategy is to substitute the objective of building

84 VITAL, C.; LOPES, P. V. L. Religião e Política. Op. Cit, pp. 131 et seq.

85 SOUZA, Sandra Duarte. “'Não à ideologia de gênero!': a produção religiosa da violência de gênero na política brasileira". In: Estudos da Religião, v. 28, n. 2, 2014, pp. 192 et seq; MIGUEL, L. F. "Da 'doutrinação marxista' à 'ideologia de gênero'”. Op. Cit., p. 599. Thus, during the debates for the approval of the PNE in the Senate, subsection II of Article 2 of the legislative project, that posits its directives, had its wording altered to remove the emphasis on the promotion of "racial, regional, gender and sexual orientation equality" to the more anodyne reference of "all forms of discrimination" (SANTIAGO, Mylene Cristina; SANTOS, Mônica Pereira dos; MELO, Sandra Cordeiro de. "Plano Nacional de Educação (2014-2024): considerações omniléticas sobre o patrulhamento ideológico e as diferenças silenciadas". In: Revista Educação e Cultura Contemporânea, v. 13, n. 22, 2016, p. 68).

86 Ibidem, pp. 596-598.

87 SOUZA, S. D. “Não à ideologia de gênero!’”. Op. Cit., p. 197. Lopes questions the idea of the defense of a "natural" sexuality in opposition of an "unnatural" one questioning the notion of nature itself. If we understand that natural is that which exists in nature, homosexual behavior is observed in various other species of animals. On the other hand, if natural means "according to nature's ends", there is the problem that nature is not prescriptive, but determinant. (LOPES, J. R. L. "O direito ao reconhecimento para gays e lésbicas". Ibidem, pp. 80-81. It should be added that talking about "natural family" sounds like nonsense, since there is no doubt that the familiar arrangements are historical constructions.

88 MIGUEL, L. F. "Da 'doutrinação marxista' à 'ideologia de gênero"”. Op. Cit., p. 597. In this sense, Natividade and Oliveira highlight the use of a naturalist worldview by the religious discourse, as a means to sustain the evidence and universality of its precepts (NATIVIDADE, M; OLIVEIRA, L. As novas guerras sexuais. Op. Cit., p. 11). 
tolerance and respect to diversity of the educational policies for that of incentive of fomenting "homosexualism" or even pedophilia or persecution and intolerance towards Christian faith ${ }^{89}$.

From 2010 onwards the conservative powers in the National Congress started to ally in a joint defense of their educational propositions. Thus, the "gender ideology" discourse joins the defense of "Escola Sem Partido". The "Escola Sem Partido" movement was established in 2004, but recently got more projection when their banners started to be embraced by conservative politicians ${ }^{90}$. The central goal of the movement is the idea that teachers were promoting "ideological indoctrination", linked to left-wing banners, communism, and PT, reason why they defend a so-called "neutral" education, that would respect student's moral integrity and the right of parents to give their children an education according to their own convictions ${ }^{91}$.

With the alliance of both agendas - that of "gender ideology" and "Escola sem Partido" - the debate started to happen in the more general scope of the dispute between school authority and family authority about the moral and political formation of children, from the idea that the parents should have the power to veto discussion in the classroom about subjects contrary to their values ${ }^{92}$. A series of legislative projects both in the House or Representatives and the Senate has aimed to promote the ideas of the movement or facing "gender ideology" "93. Moreover, similar proposals have been introduced in many States and Municipalities, some of which were approved by local legislative bodies ${ }^{94}$. Effectively, the "Escola Sem Partido" website

89 NATIVIDADE, M; OLIVEIRA, L. As novas guerras sexuais. Op. Cit., p. 114.

90 MIGUEL, L. F. “Da 'doutrinação marxista' à 'ideologia de gênero'”. Op. Cit., p. 595.

91 AMORIM, Marina; SALEJ, Ana Paula. "O conservadorismo saiu do armário: a luta contra a ideologia de gênero do movimento escola sem partido". In: Revista Ártemis, vol. XXII, n 1 , 2016, p. 33.

92 MIGUEL, L. F. "Da 'doutrinação marxista' à 'ideologia de gênero'”. Op. Cit., pp. 596 e 601. This banner of parental authority is usually backed up by Article 12.4 of the San José of Costa Rica Pact, according to which "Parents, and whenever the case the tutors, have the right that their children or pupils receive the moral and religious education that is in accordance with their own convictions".

93 For a complete list of the projects and their individual scopes, see MIGUEL, L. F. "Da “doutrinação marxista' à 'ideologia de gênero"”. Op. Cit., pp. 604 et seq, e SANTIAGO, M. C.; SANTOS, M. P.; MELO, S. C. "Plano Nacional de Educação (2014-2024)”. Op. Cit., pp. 73 et seq.

94 Thus, e.g., Municipal Law n. 5.165/2015, of Volta Redonda, that prohibited the "implantation of the policy of gender ideology in the Municipal Education establishments of Volta Redonda", recently found unconstitutional by the District Court of Rio de Janeiro (Representação de Inconstitucionalidade $\mathrm{n}^{\circ} 0007584-60.2016 .8 .19 .0000$ ), that adduced that "adopting a prohibitive position towards information and dialogue would bring forth discriminatory treatment, creating obstacles to the promotion of citizenship and equality, against the State Constitution and Federal 
has many "model projects" for municipal and state laws that can be put forward by assemblymen, expressly talking about the gender and sexuality discussion ${ }^{95}$.

All these proposals are based on two pillars: that of family sovereignty that defends an idea that this is an entity with independent rights to those of their individual members, with the prevalence of parents over their children ${ }^{96}$; and that of education neutrality that understands that the teacher should merely "teach the book" without any kind of personal or critical opinion.

The "family sovereignty" is used to try and seal the school debate about sexual diversity and, thus, the adoption of proposals for facing homophobia. That is because this idea bases itself on the defense of the primacy of family over school in any debate of "moral" order, what ends up prohibiting an education that contributes with values of tolerance and respect towards difference. It is a dispute about the frontiers between "public" and "private". On the other hand, the gender and sexual diversity debate is seen as a strategy to destroy the "natural family" (i.e. patriarchal and heteronormative). If the traditional family and gender roles are absolute and immutable, be it through "scientific" arguments, be it through religious arguments, there cannot be a discussion, since "the natural and divine order is, by definition, indisputable" $"$.

The defense of neutrality in education aims to reduce the act of teaching to the mere mechanical transmission of objective curricula, without critique and context, ignoring the interaction between the teacher and students, understood as mere receptacles and passive subjects in the educational process. Firstly, this notion ignores that knowledge is necessarily localized and thus neutrality is not possible since the selection of objective curricula is in itself a political decision. Secondly, neutrality incurs in the crystallization of inequality and injustice, since it "projects an education that is not capable of intervening in the world and, thus, is an accomplice of injustices and violences that happen"'98.

Constitution. It is without doubt, then, that the Volta Redonda City Council, in editing this norm, prohibiting the implantation of the policy of gender ideology in the education establishments of Volta Redonda violated, at once, the constitutional principle of equality in the structural aspect (right to non-discrimination), the fundamental right to difference, the republican model of the Brazilian State, based on political pluralism, and the principle of State secularism".

95 AMORIM, M.; SALEJ, A. P. “O conservadorismo saiu do armário”. Op. Cit., pp. 33-34.

96 This tension between family sovereignty to one side and the State and school to the other had already been debated in the so called Lei da Palmada ou Lei Menino Bernardo (Law ${ }^{\circ}$ $13.010 / 2014$ ) that prohibited physical punishment both in schools and families, reducing the liberty of parents in their children education.

97 MIGUEL, L. F. “Da 'doutrinação marxista’ à 'ideologia de gênero'”. Op. Cit., p. 613.

98 Ibidem, p. 615. 
In a similar sense, Sarmento understands that beyond the quest for a supposed neutrality, oftentimes hides a defense of the maintenance of the status quo $^{99}$. Thus, education neutrality in gender, sexuality, and family conceptions does not represent the defense of "no model", but of an hegemonic model ${ }^{100}$. It begs the question of to which measure this soidisant neutral education, but actually localized and oppressive, attends to the constitutional mandate of overcoming the cultural standards that produce inequality and injustice ${ }^{101}$.

This defense of neutrality in education, allied to the idea of "family sovereignty" aims to take moral and "political" themes from school's (public) scope and to the parent-children (private) relationship. A first reading could take us to believe that this movement adjusts itself to the liberal conceptions that value individual autonomy to decide their own existential projects against State intervention. This perspective ignores, however, that there is no real consideration for individual selfdetermination in this case, since the choices are made by the parents in lieu of their children. On the other hand, the fact that children and teenagers are subjects in formation imposes certain modulations to their self-determination capacity. Moreover, the 1988 Constitution posits a project of active intervention in reality to overcome prejudice and discrimination, which puts in check the absolute defense of State neutrality. According to Sarmento:

The guarantee of liberty itself justifies that the State abandons its supposed worldview neutrality to favor, as a rule, without coercion, "good life" understandings that, adopted by people, propitiates a more hospitable cultural ambient for the development of each member of society's personality. If the effective exercise of liberty by concrete persons is fiercely conditioned by the cultural atmosphere

99 SARMENTO, D. Dignidade da Pessoa Humana. Op. Cit. p. 173.

100 Thus: "the school is part of a society where there is extreme gender inequality; thus if it does not defend a pedagogical proposal that intervene in these questions, it will only reproduce injustice, violence, discrimination, exclusion, and marginalization. Education, if committed to social equality and inclusion, can be a privileged path to emancipation" (LINS, B. A.; MACHADO, B. F.; ESCOURA, M. Diferentes, não Desiguais. Op. Cit, pp. 101-102).

101 In this sense: "in incorporating into legislative lingo the term 'gender ideology', MESP fights for the prohibition of the terms "gender" and "sexual orientation" in the school vocabulary, wanting to avoid any kind of questioning of the naturalized perception of gender roles. Thus, when it takes the banner of neutrality, the movement refers itself to a discourse that does not question the world as it is and blocks any potential of change. Its idea of neutrality is based on the fiction of a knowledge that is not socially localized. In reality, this neutrality does not exist, since any production of knowledge comes from a specific social place (AMORIM, M.; SALEJ, A. P. “O conservadorismo saiu do armário”. Op. Cit., p. 38) 
in which they are inserted, as mentioned above, it seems evident that a State that values individual autonomy should not be indifferent in relation to the present culture. ${ }^{102}$

Thus, we can conclude that there is a contest about the role of the State and the public sphere in general should take in face of prejudice and asymmetric cultural standards born from religious or moral "private" views. School takes a central role in this tension due to its transforming role endorsed by the 1988 Constitution, that puts in check the limits and localizations of a supposed "neutrality" that education should adopt in face of an unequal reality and the imposition of values in the family ${ }^{103}$.

102 SARMENTO, D. Dignidade da Pessoa Humana. Op. Cit., p. 174. In this sense, the author gives an eloquent example and quite related to the theme of the present article: "The State should not keep neutral in the dispute between equalitarian and sexist worldviews. It can should - chose the first and favor them, e.g., in the definition of school curricula, in public policy, in the symbolic acts. It should do so, so that society as a whole turns into a space more conducive for concrete and real people to experience their liberty, in a cultural ambiance that does not oppress or stigmatize them" (Loc. Cit.).

103 We highlight that these conclusions were also taken by the Federal Attorney's Office for the Rights of the Citizen, linked to the Attorney-General of the Republic, in the Technical Note 01/2016 PFDC, relating to the legislative proposition that aims to implement the "Escola sem Partido" program, in verbis: "What shows, thus, in the Legislative project and its inspiring document is the nonconformity with the victories of many emancipative struggles in the constitutint process; with the formation of a society that has to be open to multiple and different worldviews; with the fact that the school is a strategic space for political emancipation and for the overcoming of sexist ideologies - that condemn women to a naturally infrior position, racists - that represent non-white as perpetual savages, religious - that presents the world as creation of the gods, and many others that aim to eliminate the contrating versions of the truths it propagates.

The Legislative project subverts the present constitutional order, for numerous reasons: (i) confuses the school education with that which is given by the parents and, with that, public and private spaces; (ii) forbids pluralism of ideas and pedagogical conceptions (Article 206, III); (iii) denies the academic freedom and possiblity of ample learning (Article 206, II); (iv) goes against the principle of State secularism, permitting that in schools, public spaces in the constitutional view, particular religious/moral views take precedence.

Finally, and graver still, the Legislative project is against the fundamental objectives of the Federative Republic of Brazil, especially those of 'building a free, just, and solidary society' and 'promoting the general good, without prejudices of origin, race, sex, color, age, and any other form of discrimination". (PROCURADORIA Federal dos Direitos do Cidadão. Nota Técnica 01/2016 PFDC. 21.07.2016. Disponível em: <http://pfdc.pgr.mpf.mp.br/temas-deatuacao/educacao/saiba-mais/proposicoes-legislativas/nota-tecnica-01-2016-pfdc-mpf $>$. Acesso em 21.04.2017). 


\section{CONCLUSION}

This article aimed to analyze the contribution the school can give in deconstructing a markedly homophobic culture. To do this, it first verified the cultural foundations in which it bases itself: compulsory heterosexuality, male domination, crystallization of gender roles, malefemale hierarchy. In this sense, based on the thought of Nancy Fraser, we concluded that homophobia represents an injustice in the cultural field, which needs recognition policies for its coping, and that these are a constitutional duty from the 1988 Charter's recommendation of a more fraternal, plural, and prejudice-less society.

Facing this scenario, we examined how the school has a central role in the production and reproduction of homophobia itself, but also how it can have the opposite function. Thus, we analyzed the potential education has for questioning and deconstructing a social standard that produces homophobia, verifying some concrete measures and policies for this. The adoption of educational public policies aiming to transform schools in emancipator spaces of tolerance is, on the other hand, questioned by conservative forces and movements that aim to maintain a status quo, and fabricate the notion of a "gender ideology" as a rhetorical artifact to oppose the school's position as an instrument against homophobia.

In this sense, the discussion about the role schools should take in facing homophobia is inserted in a more general context of constitutional meaning disputes between conservative groups of "defense of the family" and groups in defense of sexual diversity, that the mobilization and debates around their banners help define the public policies adopted by the State. Thus, Junqueira understands that:

The creation of the conditions to deal adequately with
themes related to sexual diversity and sexual rights
in schools depends, mostly, on educational public
policy and social mobilization that aim to destabilize
the production of hierarchies, oppressions, and
chasms concerning both heteronormative standards,
that historically modulate gender relations, and (re)
production of differences and inequality dynamics ${ }^{104}$.

This article, it begs to stress, explicitly takes one of the sides in this dispute, effectively defending that it is required by the 1988 constitutional order. More than that, the adoption of recognition politics in the school ambiance is a requirement of justice according to Nancy

104 JUNQUEIRA, R. D. "Políticas de educação para a diversidade sexual”. Op. Cit., p. 163. 
Fraser's theory, since only an education committed to tolerance and respect towards sexual diversity, in which there is no "homophobia pedagogy", can produce subjects committed to cultural standards of respect and help produce effectively participation parity.

\section{RERFERENCES}

AGUIÃO, Silvia; VIANNA, Adriana; GUTTERRES, Anelise. "Limites, espaços e estratégias de participação do movimento LGBT nas políticas governamentais". In: LOPES, José Sergio Leite; HEREDIA, Beatriz (orgs.). Movimentos Sociais e Esfera Pública: o mundo da participação. Rio de Janeiro, CBAE, 2014, pp. 238-269.

ALMEIDA, Edson Leandro de. Escola sem Homofobia: a (re)produção da identidade sexual nos discursos escolares. (Dissertação de Mestrado). Programa de Pós-Graduação em Educação, Culturas e Identidades. Universidade Federal Rural de Pernambuco, Recife, 2016, 105p.

AMORIM, Marina; SALEJ, Ana Paula. "O conservadorismo saiu do armário: a luta contra a ideologia de gênero do movimento escola sem partido". In: Revista Ártemis, vol. XXII, n 1, 2016, pp. 32-42.

BARROSO, Luís Roberto; OSÓRIO, Aline Rezende Peres. "Sabe com quem está falando?": Algumas notas sobre o princípio da igualdade no Brasil contemporâneo. 24p. Disponível em: $<$ http://www. luisrobertobarroso.com.br/wp-content/themes/LRB/pdf/SELA_Yale_ palestra_igualdade_versao_fina.pdf $>$. Acesso em: 21.04.2017.

BARRETO, Ana Luiza Cruz Sá. A escola e o seu papel na construção de diferentes identidades sociais. (Dissertação de Mestrado). Curso de Mestrado em Psicologia. Centro Universitário de Brasília, Brasília, 2016, 210p.

BENTO, Berenice. "Na escola se aprende que a diferença faz a diferença". In: Estudos Feministas, 19(2), 2011, pp. 548-559.

BORRILLO, Daniel. Homofobia: história e crítica de um preconceito. Belo Horizonte: Autêntica, 2010, 142p.

BRUM, Eliane. "Escola Sem Pinto". El País. Opinião. Publicado em 17.04.2017. Disponível em <http://brasil.elpais.com/brasil/2017/04/17/ opinion/1492435392_872941.html>. Acesso em 21.04.2017.

BUTLER, Judith. Problemas de Gênero: feminismo e subversão da identidade. $8^{a}$ Ed. Rio de Janeiro: Civilização Brasileira, 2015, 287p.

CARRARA, Sérgio. "Políticas e direitos sexuais no Brasil contemporâneo". In: Bagoas, no 05, 2010, pp. 131-147.

CASTELLS, Manuel. O poder da identidade. $8^{\mathrm{a}}$ Ed. São Paulo: Paz e 
Terra, 1999, 530p.

CASTRO, Carlos Roberto Siqueira. "A nova dimensão da igualdade". In: CASTRO, Carlos Roberto Siqueira. Constituição Aberta e os Direitos Fundamentais: Ensaios sobre o constitucionalismo pós-moderno e comunitário. $2^{\text {a }}$ Ed. Rio de Janeiro: Forense, 2010, pp. 357-435.

COHEN, Jean L. "Repensando a privacidade: autonomia, identidade e controvérsia sobre o aborto". In: Revista Brasileira de Ciência Política, $\mathrm{n}^{\circ}$ 7. Brasília, janeiro/abril de 2012, pp. 165-203.

CONSELHO Nacional de Combate à Discriminação. Brasil Sem Homofobia: Programa de combate à violência e à discriminação contra GLTB e promoção da cidadania homossexual. Brasília: Ministério da Saúde, 2004, 32p. Disponível em: <http://bvsms.saude.gov.br/bvs/ publicacoes/brasil_sem_homofobia.pdf>. Acesso em: 21.04.2017.

DINIZ, Debora; LIONÇO, Tatiana. "Educação, direitos sexuais, laicidade e diversidade sexual". In: In: RIOS, Roger Raupp; GOLIN, Célio; LEIVAS, Paulo Gilberto Cogo. Homossexualidade e Direitos Sexuais: reflexões a partir da decisão do STF. Porto Alegre: Sulina, 2011, pp. 125-146.

ERIBON, Didier. Reflexões sobre a questão gay. Rio de Janeiro: Companhia de Freud, 2008, 455p.

FRASER, Nancy. "Social Justice in the Age of Identity Politics: Redistribution, Recognition, and Participation”. In: FRASER, Nancy; HONNETH, Axel. Redistribution or Recognition?: a political-philosophical exchange. Londres: Verso, 2003. pp. 7-109.

FRASER, Nancy “Distorted Beyond All Recognition: A rejoinder to Axel Honneth". FRASER, Nancy; HONNETH, Axel. Redistribution or Recognition?: a politicalphilosophical exchange. Londres: Verso, 2004, pp. 198-236.

FRASER, Nancy. "Repensando a questão do reconhecimento: superar a substituição e a reificação na política cultural”. In: BALDI, César Augusto. (org.). Direitos Humanos na Sociedade Cosmopolita. Rio de Janeiro: Renovar, 2004, pp. 601-621.

FRASER, Nancy. "Redistribuição, Reconhecimento e Participação: por uma Concepção Integrada de Justiça”. In: SARMENTO, Daniel; IKAWA, Daniela; PIOVESAN, Flávia. (coords.). Igualdade, Diferença e Direitos Humanos. Rio de Janeiro: Lumen Juris, 2010, pp. 167-190.

FRY, Peter. "Diferenças, desigualdade e discriminação". In. LIMA, Antonio Carlos de Souza (coord.). Antropologia \& Direito: temas antropológicos para estudos jurídicos. Rio de Janeiro/Brasília: Contra Capa, 2012, pp. 227-233.

JUNQUEIRA, Rogério Diniz. "Homofobia: limites e possibilidades de um conceito em meio a disputas”. In: Revista Bagoas, V.1, n.1, jul./dez. 2007, 22p.

JUNQUEIRA, Rogério Diniz. "Políticas de educação para a diversidade sexual: escola 
como lugar de direitos. In: LIONÇO, Tatiana; DINIZ, Debora. (Orgs.). Homofobia \& Educação: um desafio ao silêncio. Brasília: LetrasLivres, EdUnB, 2009, pp. 161-193.

JUNQUEIRA, Rogério Diniz. "Pedagogia do armário e currículo em ação: heteronormatividade, heterossexismo e homofobia no cotidiano escolar". In: MISKOLCI, Richard; PELÚCIO, Larissa (orgs.). Discursos fora da ordem: sexualidades, saberes e direitos. São Paulo: Annablume, Fapesp, 2012, pp. 277-306.

LINS, Beatriz Accioly; MACHADO, Bernardo Fonseca; ESCOURA, Michele. Diferentes, não Desiguais: a questão de gênero na escola. São Paulo: Reviravolta, 2016,142p.

LIONÇO, Tatiana; DINIZ, Debora. "Homofobia, silêncio e naturalização: por uma narrativa da diversidade sexual". In: LIONÇO, Tatiana; DINIZ, Debora. (Orgs.). Homofobia \& Educação: um desafio ao silêncio. Brasília: LetrasLivres, EdUnB, 2009, pp. 47- 71.

LOPES, José Reinaldo de Lima. “O direito ao reconhecimento para gays e lésbicas”. In: Sur - Revista Internacional de Direitos Humanos, ano 2, Número 2, 2005, pp. 64-95.

MARMELSTEIN, George. "Jurisprudência arco-íris: comentários à decisão do Supremo Tribunal Federal acerca das uniões homoafetivas”. In: Revista Brasileira de Direito Constitucional - RBDC n. 17 - jan./jun. 2011, pp. 225-262.

MIGUEL, Luis Felipe. “Da 'doutrinação marxista’ à 'ideologia de gênero’: Escola sem Partido e as leis de mordaça no parlamento brasileiro”. In: Direito \& Práxis. Rio de Janeiro, Vol. 07, nº 15, 2016, pp. 590-621.

MISKOLCI, Richard. Teoria Queer: um aprendizado pelas diferenças. 2a Ed. Belo Horizonte: Autêntica, 2015, 82p.

NATIVIDADE, Marcelo; OLIVEIRA, Leandro de. As novas guerras sexuais: diferença, poder religioso e identidades LGBT no Brasil. Rio de Janeiro: Garamond, 2013, 304p.

PERES, William Siqueira. "Cenas de exclusões anunciadas: travestis, transexuais e transgêneros e a escola brasileira”. In: JUNQUEIRA, Rogério D. (Org.). Diversidade Sexual na Educação. MEC/Unesco, 2009, pp. 235-263.63.

PEREIRA, Jane Reis Gonçalves. "A aplicação de regras religiosas de acordo com a lei do Estado: um panorama do caso brasileiro". In: Revista da AGU, v. 41, 2014, pp. 9-42.

PIOVESAN, Flávia. Temas de Direitos Humanos. 3ª Ed. São Paulo: Saraiva, 2009, 415p.

PROCURADORIA Federal dos Direitos do Cidadão. Nota Técnica 01/2016 PFDC. 21.07.2016. Disponível em: <http://pfdc.pgr.mpf.mp.br/temas-de-atuacao/educacao/ saiba-mais/proposicoes-legislativas/nota-tecnica-01-2016-pfdc-mpf $>$. Acesso em 21.04.2017.

RIOS, Roger Raupp. "O conceito de homofobia na perspectiva dos direitos humanos e no contexto dos estudos sobre preconceito e discriminação”. In: RIOS, Roger Raupp. (org.). Em Defesa dos Direitos Sexuais. Porto Alegre: Livraria do Advogado Ed., 2007, pp. 111-139. 
RIOS, Roger Raupp. "Direito da antidiscriminação, sexo, sexualidade e gênero: a compreensão da proibição constitucional de discriminação por motivo de sexo". In: SARMENTO, Daniel; IKAWA, Daniela; PIOVESAN, Flávia (coords.). Igualdade, Diferença e Direitos Humanos. Rio de Janeito: Lumen Juris, 2010, pp. 695-717.

RIOS, Roger Raupp; SANTOS, Wederson Ruffino dos. "Diversidade sexual, educação e sociedade: reflexões a partir do Programa Nacional do Livro DidáticoIn: LIONÇO, Tatiana; DINIZ, Debora. (Orgs.). Homofobia \& Educação: um desafio ao silêncio. Brasília: LetrasLivres, EdUnB, 2009, pp. 133-159.

SANTIAGO, Mylene Cristina; SANTOS, Mônica Pereira dos; MELO, Sandra Cordeiro de. "Plano Nacional de Educação (2014-2024): considerações omniléticas sobre o patrulhamento ideológico e as diferenças silenciadas". In: Revista Educação e Cultura Contemporânea, v. 13, n. 22, 2016, pp. 67-83.

SANTOS, Boaventura de Sousa. Reconhecer para Libertar: Os caminhos do cosmopolitismo multicultural. Rio de Janeiro: Civilização Brasileira, 2003, 614p.

SARMENTO, Daniel. “AIgualdade Étnico-Racial no Direito Constitucional Brasileiro: Discriminação 'De Facto', Teoria do Impacto Desproporcional e Ação Afirmativa”. In: SARMENTO, Daniel. Livres e Iguais: Estudos de Direito Constitucional. Rio de Janeiro: Lumen Juris, 2006, pp. 139-166.

SARMENTO, Daniel. "Casamento e União Estável entre Pessoas do Mesmo Sexo: perspectivas constitucionais”. In: SARMENTO, Daniel; IKAWA, Daniela; PIOVESAN, Flávia (coords.). Igualdade, Diferença e Direitos Humanos. Rio de Janeiro: Lumen Juris, 2010, pp. 619-659.

SARMENTO, Daniel. "Ensino religioso nas escolas públicas". Jota. Publicado em 23.06.2015. Disponível em: <https://jota.info/artigos/ensino-religioso-nas-escolaspublicas-23062015>. Acesso em 21.04.2017.

SARMENTO, Daniel. Dignidade da Pessoa Humana: conteúdo, trajetórias e metodologia. Belo Horizonte: Fórum, 2016, 376p.

SOUZA, Elizeu Clementino de. "Direitos humanos e diversidade sexual na escola: homofobia, trabalho docente e cotidiano escolar". Conjectura: filosofia e educação; v. 20, $\mathrm{n}^{\mathrm{o}}$ especial, 2015, pp. 198-220.

SOUZA, Sandra Duarte. “'Não à ideologia de gênero!': a produção religiosa da violência de gênero na política brasileira”. In: Estudos da Religião, v. 28, n. 2, 2014, pp. 188-204.

TEIXEIRA, Adla Betsaida Martins; FREITAS, Marcel de Almeida. "Homofobia e misoginia na escola: enfrentamento a partir dos direitos humanos". In: Teoria \& Sociedade, $\mathrm{n}^{\mathrm{o}} 21.2,2013$, pp. 292-305.

TREVISAN, João Silvério. Devassos no Paraíso: a homossexualidade no Brasil, da colônia à atualidade. $8^{\mathrm{a}}$ Ed. Rio de Janeiro: Record, 2011, 588p.

VECCHIATTI, Paulo Roberto Iotti. "Fundamentos em prol da Criminalização 
da Homofobia e da Transfobia”. Jota. Publicado em 07.07.2016. Disponível em < https://jota.info/artigos/fundamentos-em-prol-da-criminalizacao-da-homofobia-e-datransfobia-07072016>. Acesso em: 21.04.2017.

VIANNA, Adriana de Resende Barreto. "Direito à Diferença: introdução". In: LIMA, Antonio Carlos de Souza (coord.). Antropologia \& Direito: temas antropológicos para estudos jurídicos. Rio de Janeiro/Brasília: Contra Capa, 2012, pp 202-211.

VITAL, Christina; LOPES, Paulo Victor Leite. Religião e Política: uma análise da atuação dos parlamentares evangélicos sobre direitos das mulheres e de LGBTs no Brasil. Rio de Janeiro: Fundação Heinrich Böll, 2012, 232p.

WELZER-LANG, Daniel. “A Construção do Masculino: dominação das mulheres e homofobia”. Estudos Feministas. Florianópolis, v. 9, n.2, 2001, pp. 460-482.

WYLLYS, Jean. Tempo Bom, Tempo Ruim: identidades, políticas e afetos. São Paulo: Paralela, 2014, 189p.

ZAMBRANO, Elizabeth; HEILBORN, Maria Luiza. "Identidade de gênero". In: LIMA, Antonio Carlos de Souza (coord.). Antropologia \& Direito: temas antropológicos para estudos jurídicos. Rio de Janeiro/Brasília: Contra Capa, 2012, pp. 413-419. 